\title{
Governing Boards in Postsecondary Education
}

\author{
JOHN D. DENNISON and ROBERT HARRIS*
}

\begin{abstract}
Since 1960 postsecondary education in Canada has been characterized by the development of a large number of non-university institutions, usually called colleges or technical institutes. Provincial government policy has been to delegate policy and management roles in these institutions to governing boards, composed largely of lay appointees. This study examines the views held by board members in one province, British Columbia, towards many of the most important issues in curriculum, management, and structure which affect the non-university sector. The results indicate that board members tend to reject strong centralization of the system. Further, they support the essential values which have characterized British Columbia colleges as comprehensive, accessible, community-based institutions governed by lay boards.
\end{abstract}

\section{RÉSUMÉ}

Depuis 1960, l'enseignement supérieur au Canada s'est largement diversifiè, surtout par la création de nouvelles institutions extra-universitaires dites "collèges" ou "instituts de technologie". La politique des gouvernements provinciaux a eu comme résultat de confier la direction et l'administration de ces institutions à des comités de "gouverneurs", composés dans leur majorité de personnes nonuniversitaires. La présente recherche étudie les attitudes des membres de tels comités d'une seule province, la Colombie-Britannique, envers certaines questions fondamentales - de programme, d'administration, et de structures - qui ont trait aux fonctions du secteur extra-universitaire. Il en résulte que ces membres rejettent la possibilité même d'une forte centralisation du système collégial. Et ils cherchent à revaloriser certaines tendances historiques des collèges colombiens: leur ampleur programmatique, leur ouverture sociale, leurs liens avec les communautés où se trouvent les collèges et d'où viennent les membres des comités gouverneurs.

* The University of British Columbia 


\section{INTRODUCTION}

While there is no period in the evolution of socio-cultural institutions in modern society which is without revision, it may be argued that Canadian education, particularly at the postsecondary level, has undergone dramatic change since the end of World War II. In two decades, 1963-1983, most provinces in Canada witnessed the adaptation of one of the most innovative of educational concepts developed in North America, the public community college.

The first ten years of this period were characterized by an unprecedented demand for educational opportunity, a relatively robust economy and an abiding public faith in and support for expansion of the postsecondary educational system. However, the decade from 1973-1983 has featured a different kind of change. New areas, i.e., health, social welfare and energy, replaced education as a social priority. General support for higher education waned as its intrinsic and extrinsic values were subject to review. But the most critical of all factors has been the declining state of the economy and the reluctance of government to keep pace with the increasing financial appetite of the education system.

British Columbia has not escaped the economic turndown and the province's colleges and institutes have experienced budgetary restraint and financial uncertainty. Either as a consequence of the economic situation, or relatively independent of it, depending on one's perspective, the British Columbia Ministry of Education has begun a serjes of planning initiatives which could usher in a new era of centralized authority in a college structure which had evolved in a climate of decentralized, community control.

It is not the objective of this paper to debate the intent, degree or wisdom of the new ministerial direction. Various organizations, groups and individuals have recorded their opinions, including faculty members, administrators and individuals associated with the province's colleges and institutes. However, there has never been a systematic attempt to assess the views of the one group which is charged with a major responsibility for the management of the colleges and institutes, specifically, the members of governing boards who develop policy for the institutions and who are intimately affected by the changes being planned for the system.

Hence, the purpose of this study was to undertake a systematic assessment of the views of board members in 1983. The issues which they were asked to address were fundamental to the future of the British Columbia college and institute system, such as curriculum content and priorities, the role and composition of institutional governing boards and the provincial governance structure. In order to place the views expressed in perspective it is first necessary to comment on the current role of college and institute boards in British Columbia.

\section{Colleges and Institutes in British Columbia}

The Province of British Columbia supf rrts three types of postsecondary institutions: universities, colleges and institutes. The university sector comes under a Ministry of Universities, Science and Technology while the colleges and institutes, together with the public schools, are the responsibility of the Ministry of Education. 
The college system began in 1965, with the establishment of Vancouver Community College. Another fourteen colleges, located throughout the province, have been added since 1965. From their inception, the colleges have reflected a community orientation and, by Canadian standards, are among the most responsive to their immediate communities. In their early years it was regional interest groups, rather than the provincial government, who carried the responsibility for establishing and developing the colleges. Even the financing formula required a local tax contribution to the operating budget.

From the beginning, the legislation which applied to the colleges has provided for a board of governors, some of whom were appointed to represent cooperating school boards and others were appointed by the provincial government. Each college board was responsible for establishing policy and the overall management of the institution. While in the period 1965-1977 the boards held no legal status, this changed with the passage of the College and Institute Act of 1977 which gave the college boards corporate status and considerable legislated authority.

In mid-1983 a college board consists of at least seven members. Each school district within a college region appoints at least one person to a college board. The remaining members, appointed by the Minister of Education, include a number equal to the school board appointees, plus one. This numerical formula reflects the provincial government's provision, since 1977, of the total operating and capital budgets. The school board appointees serve for one year and are eligible for reappointment. The ministerial appointees serve for up to two years and their term may also be extended.

Under the current legislation the mandate for the colleges is expressed in general terms as follows. . .

"The objects of a college are to provide comprehensive

(a) courses of study equivalent to those given by a university at the first and second year level;

(b) postsecondary education or training; and,

(c) continuing education." (College and Institute Act, Section 7)

Besides the fifteen colleges there are six provincial institutes. As their name implies, the institutes hold a province-wide mandate. Their programs are designed to meet the needs of certain types of specialized education and training for the entire province. The first such institution, the British Columbia Institute of Technology (B.C.I.T.), opened in 1964 and has been constituted under its own Act since 1973. The other institutes are the Justice Institute, Pacific Marine Training Institute, Open Learning Institute, Pacific Vocational Institute, and the Emily Carr College of Art. In keeping with their provincial mandates, the governing boards of the institutes, except B.C.I.T., consist of at least nine members all of whom are appointed by the Lieutenant Governor in Council and have no regional restrictions upon their eligibility. They serve for two years and are eligible for reappointment.

Unlike the colleges, the legislated mandate for the institutes, with respect to curriculum, is quite unspecific. 
"The objects of an institute are to provide instruction and perform other functions as designated by the minister."

(College and Institute Act, Section 10)

The B.C. Institute of Technology is governed by a board which includes faculty, staff and student representation, in addition to ministerial appointees. In no other cases are employees, including administrators or students eligible to serve on governing boards of colleges or institutes.

In addition to the boards, the structure in British Columbia includes three quasi-independent intermediary bodies called Councils. The Occupational Training Council, the Academic Council and the Management Advisory Council are responsible for the allocation of provincial funds to the appropriate programs and services offered by the institutions.

\section{The Roles and Powers of Boards}

Although a considerable amount of literature concerned with higher education institutional boards has been published in the United States, only limited study has been reported in Canada. However, Canadian issues in governance do exist and several papers, notably those of Konrad (1975, 1977, 1980), Gray (1975), and Kelly (1973), make reference to the issues of membership composition, degree of independence and amount of responsibility which relate to the role of boards.

Referring to the governing structure of Dawson College in Montreal, Kelly (1973) states that the college board was regarded as the most successful of college-wide bodies and never had the board divided according to constituency on a vote on any issue. In Quebec the college boards consist of government appointees plus representatives drawn from parents, faculty, students, administration, and other groups.

On the matter of independence of boards, particularly from the priorities of the government to which many members owe their appointments, Konrad also makes a particular reference to British Columbia:

"Although the main challenges to a board's independence come primarily from political office holders, they can also come from within - from the very composition of the board itself. When a trustee serves by virtue of membership in another organization, as is the case with a majority of board members in British Columbia who represent local public school districts, jurisdictional independence can suffer severely. Leaving aside such matters as individual energy, time, and rapid turnover, the question arises: Can a trustee unreservedly give his or her allegiance to the college when prior commitment has been made to the local school district?" (Konrad, 1980:104)

A study, published in 1977 by the same author, produced a composite description of the "typical" board member in Canada as follows:

"... .male, in his middle forties, a long-time resident of the province, and living within the same city or town as the college. He is highly educated, a member of a profession, and well-off financially. Ideo- 
logically, he views himself as a liberal, and he is a member of the political party in power provincially. He is newly appointed, and has not previously served on a college board." (Konrad, 1977:72)

While these qualities are largely personal, Konrad also examined those characteristics which board members themselves viewed as important in their colleagues. The top five, in order, were as follows:

1. Interest in higher education.

2. Vision to move ahead.

3. Understanding of institutional role.

4. Time to devote to board activity.

5. Involvement in community affairs.

It is of interest to note that "business knowledge" was sixth and "involvement in party politics" was at the end of the list.

Gray in 1975 completed a doctoral dissertation on problems of governance in British Columbia colleges. One significant conclusion was that one of the major problems encountered by the boards was lack of continuity among their members. The constant turnover in membership made long term planning and commitment a difficult enterprise.

Any attempt to appreciate the powers of college and institute boards must begin with a discussion of parliamentary governance as practised in Canada. Under Section 93 of the British North America Act, education at all levels is under the jurisdiction of the provinces. Provincial legislative bodies are responsible for overall policy, control and financing of the educational system. Under the appropriate legislation, in this instance the B.C. College and Institute Act and the British Columbia Institute of Technology Act, particular responsibilities are delegated to a number of management agencies which assist the Minister of Education in the operation of the system. One of these agencies is the board of each institution.

In the College and Institute Act, Section 12, the powers of a board are delineated. These include powers to:

". . .manage, administer and direct the affairs of the institutions and establish committees it considers necessary and advisable;

...manage and promote the educational or training programs offered at the institutions;

...prepare and submit budgets, financial statements and other reports as requested by the Minister;

...make bylaws . . .about... the powers, duties and benefits of the principal... [tuition] fees...; and,

...perform other functions not inconsistent with the Act that the board considers advisable for the proper administration and advancement of the institution. (College and Institute Act: Section 12)

Konrad (1980), in his review of community college boards, makes reference to one aspect of such a study when he notes that,

"Studies of provincial systems of postsecondary education during the past decade or so clearly indicate a change in the balance between 
institutional authority and governmental control. Trustees find themselves in the midst of this turmoil. As the trend toward centralization increases and as greater demands for participation in governance are made by both faculty and students, the composition of boards of trustees and their roles require closer examination and possible redefinition. (Konrad, 1980:96)

In light of the foregoing the views and opinions of board members, both individually and collectively, towards the general issues which affect the college and institute system need to be assessed, analysed and the results considered as part of any planning process. No systematic attempt at such a task has been conducted in British Columbia. Hence, the motivation for this study.

\section{Design of the Study}

A number of "key" issues affecting the college and institute system in British Columbia were selected after a series of consultations with qualified individuals, none of them board members. The final selection of issues included:

a) Program offerings and priorities in the institutions.

b) The role and composition of boards.

c) Extra-institutional governance.

While many of the specific questions were selected with the current planning activity of the Ministry of Education in mind, other questions had a long term implication and were more fundamental to the role of the college and institute sector of postsecondary education in British Columbia. Finally, certain demographic data were requested to permit analysis based upon critical differences among board members, such as experience and whether they were school board or ministerial appointees. The penultimate instrument was field tested with one college and one institute board. Minor changes were made as a result. All active board members in the province were sent the final questionnaire by mail and one "follow-up" letter was sent.

\section{Response Rate}

At the time of the study a total of 230 individuals served on the college and institute boards in the province. Of this number 179 served on college boards and 51 on institute boards. The overall response rate was $65 \%$, including 118 $(66 \%)$ from colleges and $32(63 \%)$ from institutes.

\section{Demographic Characteristics of Respondents}

Source of appointment: In the college sector, 52 (44\%) were appointees from cooperating school boards, while $66(56 \%)$ were government appointees. In the institute sector all members are appointed by the provincial government, except in the case of B.C.I.T. which has elected members, from faculty, staff and students.

Location of institutions: A total of 76 respondents represented "metropolitan" based institutions while 70 were from "non-metropolitan" colleges. For the purpose of this study institute board members were classified as metropolitan 
because all of the institutes are located in the Vancouver metropolitan area. Of the 76 responses from the metropolitan board members 45 were from colleges and 32 were from the institutes.

Experience on boards: Sixty-six respondents (44\%) had a maximum of two year's experience, while $84(56 \%)$ reported three or more years of experience on the board.

Previous experience: Slightly over half of the respondents reported previous experience on a school or similar type board. College board members in metropolitan based institutions had $66 \%$ with previous experience and the non-metropolitan had $48 \%$. The institute board members had $45 \%$ with previous experience.

\section{Representativeness of Respondent Group}

Based on the known demographic characteristics of college and institute board members in the province at the time of the study, the respondent group was representative of the total population of board members. This factor, coupled with the response rate provided an acceptable level of confidence in the results of the study.

\section{RESULTS}

The results of the study are reviewed first with respect to educational programs, then to board roles and composition, and finally to issues related to extrainstitutional governance.

\section{Educational Programs}

The concept of the comprehensive curriculum has long been a feature of British Columbia's colleges. Institutes have been more specialized, but with the exception of the academic, or university-equivalent courses, the institute curricula offer a wide range of job-oriented and continuing education programs at various levels.

It was interesting to note that $90 \%$ of the institute board members responded to questions about college program offerings while only $70 \%$ of the college group responded to the questions relating to institute curricula. The results are shown in Table 1.

In response to questions on curriculum, board members strongly favored the retention of all current programs in the colleges. More detailed analysis showed few variations in responses by the various sub-criteria used. However, some differences are worthy of note. College board members appeared to be more supportive than institute board members of vocational programs ( $79 \%$ to $31 \%$ ) and of career/technical programs ( $82 \%$ to $55 \%)$ in colleges. The response, however, to the institute curricula question was somewhat different. While there was evidence of strong support for career/technical and vocational programs, there was less for remedial and academic programs. Clearly, the board members supported the specialized nature of the institutes. Also with respect to institute curricula, it was noted that college board members were less in favor of continuing education programs than institute board members. This may have been caused by different 
TABLE 1

Support for College \& Institute Program Offerings

Options

College

$\%$

Institute

$\%$

Academic

Career/Technical

Continuing Education

Remedia1 (Adu1t Basic..)

interpretations of the meaning of continuing education by each of the two groups. Institute based members would likely think of post-diploma training as continuing education while college based board members would likely think of community oriented programs or "not for credit" programs.

A related question was asked regarding the priority which should be assigned to the various program areas of the colleges and institutes. About $14 \%$ of the respondents were unwilling to respond to this question for colleges and in the case of the institutes, $48 \%$. Respondents noted in most cases; that it was "unfair" or "impossible" to give a priority and that, for the colleges, "all programs are essential".

The results for those who did respond were as follows: with respect to colleges, $61 \%$ of the board members placed highest priority upon academic (university transfer) programs, $27 \%$ indicated career/technical as highest, while vocational, continuing education, and remedial programs attracted $17 \%, 6 \%$, and $2 \%$ respectively. (The sum of the responses exceeded $100 \%$ because some respondents scored several programs equally first in priority.)

However, the ranking for colleges using the combined 1st and 2nd priorities were:

$\begin{array}{ll}\text { Academic } & 78 \% \\ \text { Career/Technical } & 55 \% \\ \text { Vocational/Occupational } & 36 \% \\ \text { Continuing Education } & 33 \% \\ \text { Remedial } & 13 \%\end{array}$

The most surprising result was the relatively low priority rating placed on college remedial programs. 
On the institute curricula priority assignment there was a clear indication that career/technical and vocational/occupational programs were important, rating $93 \%$ and $87 \%$ respectively in the combined 1 st and 2 nd priorities. Remedial and academic rated only $6 \%$ and $12 \%$, and continuing education $13 \%$. Only $55 \%$ of college board members responded to this question on institute program priorities.

\section{Assignment of Responsibilities}

Under the British Columbia system the Ministry of Education, three councils and the boards are all involved in particular tasks regarding the college and institute system governance. Board members were asked to indicate which agency, or combination of agencies, should be held responsible for a list of thirteen activities (Table 2). The respondents gave the Ministry of Education responsibility

TABLE 2

Responsibility Assignment

\begin{tabular}{lcccc}
\hline & \multicolumn{3}{c}{ Agency } & Designation \\
Activities & $\begin{array}{c}\text { Ministry } \\
\%\end{array}$ & $\begin{array}{c}\text { Councils } \\
\%\end{array}$ & $\begin{array}{c}\text { Boards } \\
\%\end{array}$ & $\begin{array}{c}\text { Other } \\
\%\end{array}$ \\
\hline Allocation Federal Funds & 83 & 26 & 22 & 5 \\
Allocation of Programs & 61 & 39 & 48 & 2 \\
Capital Projects & 80 & 24 & 55 & 1 \\
New Program Approval & 51 & 32 & 74 & 1 \\
Assess Provincial Needs & 81 & 37 & 23 & 3 \\
Assess Regional Needs & 43 & 26 & 72 & 5 \\
Collective Bargaining & 28 & 3 & 72 & 5 \\
Formula Funding & 76 & 33 & 43 & 3 \\
Program Evaluation & 32 & 29 & 76 & 10 \\
Program Funding & 74 & 25 & 47 & 4 \\
Long Range System Planning & 76 & 39 & 78 & 3 \\
Rationalization of System & 64 & 34 & 54 & 6 \\
Set Tuition Fees & 31 & 11 & 84 & 2 \\
\hline
\end{tabular}


for the allocation of federal funds to institutions, for the assessment of provincial educational program needs, for the development of an operating budget funding formula, and for funding programs. Boards were assigned responsibility for the approval of new programs, for the assessment of regional needs, for collective bargaining, for program evaluation and for setting tuition fees.

The respondents indicated that the Ministry of Education, the boards and to a lesser extent the councils should have joint responsibility for the allocation of programs to institutions, for approval of capital proposals, for long range planning and for rationalizing the system.

Evidently, the board members were uncertain about a role for the councils a view consistent with their responses to other questions.

\section{Role and Composition of Boards}

a) Board Activities

Table 3 summarizes the responses to a set of specific activities which board members were asked to consider as being appropriate or not for college and institute boards. Policy making, long range planning, operating and capital budgeting, and evaluation of administration ranked highest. Determining student admission qualifications and evaluation of instruction ranked lowest.

There were very small differences among the sub-groups. Institute board members seemed to be more in favor of involvement in the budgeting and planning process than college board members. On the other hand, college board members favored program approval, bargaining with instructors and support staff and cooperative planning more than did institute board members. Those with previous board experience favored involvement in staff appointments (63\%) while those without previous experience did not $(42 \%)$. Also, in the category of previous experience versus no previous experience a difference in the cooperative planning item was noted at $80 \%$ vs. $60 \%$ respectively.

\section{b) Collective Bargaining}

The views expressed in response to a specific question on collective bargaining were consistent with the overall assignment of collective bargaining to boards. Respondents were asked to express their views on province-wide bargaining, twotier bargaining (negotiating salary provincially and working conditions locally, for example), or a continuation of the present system of individualized institutional bargaining. Over $61 \%$ favored the current system, while the other two options were split evenly at $15 \%$.

Institute board members were much more in support of the present system than college board members ( $72 \%$ vs. $59 \%$ ). However, a higher percentage of the latter favored two-tiered bargaining than the institute respondents (18\% vs.3\%). Non-metropolitan college board members were far more inclined to provincewide bargaining than the metropolitan college members ( $31 \%$ vs. $14 \%$ ). 
23 Governing Boards in Postsecondary Education

TABLE 3

Support for Board Activities

\begin{tabular}{lccc}
\hline & Respondents & Institutional Type \\
Options & $\begin{array}{c}\text { College } \\
\%\end{array}$ & $\begin{array}{c}\text { Institute } \\
\%\end{array}$ & $\begin{array}{c}\text { Combined } \\
\%\end{array}$ \\
\hline Appoint Staff & 55 & 50 & 54 \\
Approve Programs & 86 & 69 & 82 \\
Bargaining with Instructors & 67 & 44 & 62 \\
Bargaining with Support Staff & 65 & 44 & 61 \\
Cooperative Planning & 76 & 56 & 72 \\
Capital Budget & 87 & 94 & 89 \\
Operating Budget & 92 & 97 & 93 \\
Admission Qualifications & 29 & 16 & 26 \\
Evaluation of Administrators & 93 & 84 & 91 \\
Evaluation of Instructors & 27 & 16 & 25 \\
Long Range Planning & 96 & 100 & 97 \\
Needs Assessment & 49 & 44 & 48 \\
Policy Making & 99 & 97 & 99 \\
Program Evaluation & 47 & 44 & \\
\hline & & & 47 \\
\hline
\end{tabular}

c) Financing Policy

Prior to 1978 , colleges were partially funded from local taxation. Respondents generally assigned overall responsibility to the Ministry of Education for funding matters, as reported above. There has been, however, some opinion expressed that it would be advantageous to return to the pre-1978 system of partial local funding. The majority $(58 \%)$ of respondents favored the current system while $39 \%$ supported a return to some local funding. College respondents favored a return to some local funding (43\%) more than institute respondents $(25 \%)$. There was little difference in response between school board and government appointed 
members. Similarly, little difference was found between metropolitan and nonmetropolitan representatives. However, the more experienced board members tended to favor a return to partial local funding in a greater proportion than those with limited experience ( $46 \%$ to $30 \%$ ).

\section{d) Tuition Fees}

The setting of tuition fees by boards was strongly supported by respondents. In response to specific questions on tuition fees, $62 \%$ of the respondents felt that tuition fees should remain at the current range, $31 \%$ were in favor of an increase. There were a number of differences which were revealed by further analysis. Increased fees were slightly favored by institute board members. The options of eliminating or reducing fees were not supported.

On the question as to whether a uniform provincial tuition fee structure should be introduced, rather than continue the present system by which fees are set by institutional boards, the majority appeared to support the present system $(58 \%$ vs. $40 \%$ ). Uniform fees tended to be more popular with non-metropolitan college board members, than any other of the sub-groups. Institute board members opposed uniform fees by $81 \%$.

\section{Board Membership}

Given the responsibility assignments and some additional specific views of board members on board level activities, the following section covers the expressed views on the composition and selection procedures for board members themselves.

\section{a) Election of Board Members}

In response to a question as to whether board members favored the principle of direct election by members of the public, the majority $(63 \%)$ replied in the negative. However, an important difference was noted between the school board and government appointees. More than half $(56 \%)$ of the school board appointees favored the election principle, while $74 \%$ of the government appointees did not agree.

\section{b) Procedures for Board Member Selection}

Table 4 shows the responses to a question as to how individuals should gain membership on college boards. Again, particular differences between college and institute respondents were noted. While the majority of the college group (56\%) favored the present system, $21 \%$ held the view that all college board members should be elected. Institute members were more evenly divided between support for the present system and a mixture of appointed and elected members. School board appointees were far more inclined towards the "all election" principle than the government appointees (33\% to $8 \%$ ). Conversely, institute respondents favored the "some appointed - some elected" option more than the college board respondents ( $32 \%$ to $14 \%)$. 
TABLE 4

Method of Selection for College Board Members

\begin{tabular}{lccc} 
& \multicolumn{2}{c}{ Respondents } \\
Options & $\begin{array}{c}\text { College } \\
\%\end{array}$ & $\begin{array}{c}\text { Institute } \\
\%\end{array}$ & $\begin{array}{c}\text { Combined } \\
\%\end{array}$ \\
\hline All Government Appointments & 7 & 16 & 9 \\
Some Appointed, Some Elected by Public & 14 & 32 & 18 \\
All Elected by Public & 21 & 3 & 17 \\
Appointed, Some Govt., Some School Bd. & 56 & 35 & 52 \\
Other & 2 & 6 & 3 \\
\hline
\end{tabular}

c) Representation on Boards

With regard to a question concerning the groups which should be represented on institutional boards, the respondents seemed to be strongly in favor of the "status quo". There was very solid support for government appointments, school board appointments and representation from the public-at-large on college boards. Other groups (students, administration, instructors) received little support, as did various interest groups which are sometimes represented on college boards in other provinces. It should be noted that the category of "public-at-large" is not mutually exclusive of other categories.

As a group, institute board members were more inclined to favor wider representation from instructors, students and special interest groups on college boards than were college board members. The more experienced members favored a more limited range of representation on their boards. There were few differences expressed with regard to institute boards, although perhaps not unexpectedly, college board members (52\%) were much more likely to check school board representation on institute boards than the institute board members (3\%), similarly with school board (60\%) appointees as opposed to government appointees $(25 \%)$. Also, institute board members favored representation from special interest groups more than college board members ( $34 \%$ to $15 \%$ ). The results are summarized in Table 5 . 
TABLE 5

Representation on Institutional Boards

\begin{tabular}{|c|c|c|}
\hline Options & $\begin{array}{c}\text { College } \\
\text { A11 Respondents } \\
\% \\
\end{array}$ & $\begin{array}{c}\text { Institute } \\
\text { All Respondents } \\
\%\end{array}$ \\
\hline Public & 65 & 71 \\
\hline School Boards & 71 & 37 \\
\hline Instructors & 18 & 20 \\
\hline Students & 22 & 24 \\
\hline Government Appointees & 75 & 77 \\
\hline Administrators & 22 & 19 \\
\hline Local Government & 15 & 13 \\
\hline Parents & 7 & 8 \\
\hline Others & 1 & 5 \\
\hline
\end{tabular}

\section{Extra-Institutional Governance}

a) Provincial Government Structure

Almost half (47\%) of the respondents favored a single Ministry of Education which would include universities, colleges, institutes and the public schools. This option was not favored by institute board members (25\%). However, a substantial minority, 30\% overall, preferred a Ministry of Advanced (or Postsecondary) Education, which would place the university, college and institute sectors under one minister of government. Further analysis showed that institute board members were more in favor of a Ministry of Advanced Education than any other single option. Also, in their case, a reasonable minority (19\%) favored an unspecified structure other than the three options listed.

In all, only $16 \%$ of the respondents supported the present structure. Few differences in opinion were noted on the basis of location, years of experience or source of appointment.

b) Council Level Structure

The view held by almost half of the respondents was that only one council should exist, with a total of $62 \%$ in favor of some form of council structure. However, a substantial minority ( $22 \%$ ) favored the abolition of the councils and the transfer of councils' responsibilities to the Ministry of Education. A minority of the institute group (13\%) checked "another form of organization" which was not specified. 
The more experienced board members, those with three or more years of service, were inclined to support a council more than the less experienced. Generally, greater experience tended to be associated with less support for abolishing councils. Perhaps this indicates a carry-over of experience from the pre-1978 years when there were no councils. Of the 17 respondents who marked the "no opinion" option, 16 had less than three years experience on the board.

\section{Comments of Respondents}

Approximately $20 \%$ of the completed questionnaires included comments. The majority were addressed to one or more of the following concerns. It must be emphasized that the number of comments were limited, in most cases, to three or four on any one issue.

$$
\begin{aligned}
\text { Curriculum - Some opinion that institute programs should be placed } \\
\text { within colleges. } \\
\text { - That colleges should surrender technical/vocational } \\
\text { courses to institutes. } \\
\text { - It was not possible or desirable to place programs in } \\
\text { priority. } \\
\text { - Comprehensiveness should be retained at all, or } \\
\text { any, cost. } \\
\text { - That all boards should be elected by taxpayers - no } \\
\text { government appointees. } \\
\text { - The public was represented through other groups. } \\
\text { - Several comments with respect to the meaning of } \\
\text { "responsibility", when applied to the roles of the } \\
\text { Ministry of Education, councils, boards, etc. } \\
\text { Bargaining - All bargaining should be eliminated - replace by "fair } \\
\text { comparison" (A bargaining option in current legis- } \\
\text { lation). }
\end{aligned}
$$

B.C. Association

of Colleges - this organization should be given formal powers and responsibilities, particularly if councils are abolished.

\section{Conclusions and Implications}

As the college and institute system in British Columbia moves toward a more centralized form of organization, the role played by the institutional boards will undoubtedly change. It is conceivable that boards will assume a higher profile than before in an attempt to protect the integrity and individuality of the institutions. The converse is also possible, in that boards might have a more limited function with greater authority vested at the provincial Ministry of Education level.

There is still another scenario. It may well be that, given the demise of the councils, the boards individually and collectively will become the major source and channel of advice to the Minister on the future program offerings and the operation of the system. In such a role, their views will become critical factors in decisions which will determine the nature of the college and institute sector of postsecondary education in B.C. 
While all of the foregoing is conjecture, it is useful to examine the results of this study which provide considerable insight into current board members' attitudes towards the educational programs offered by the system as well as its organization and operation. Apart from the fact that no systematic attempt at this task has previously been undertaken, the results should be given careful consideration by those planning for the future. Board members, after all, are given legislative authority for institutional management, which is the key factor in how effectively the educational programs are delivered to students.

\section{(a) Educational Programs}

The very strong view that colleges should preserve a comprehensive curriculum was consistent with other data which reflects support among board members for the community based, multi-purpose college. Board members obviously view the colleges as general purpose community resources. It is also interesting to note the overall support for continuing education and remedial programs in colleges. Yet when forced to address the question of priorities remedial programs came last. This result may be a reflection of the values held by board members and suggests a profile similar to that described by Konrad (1977:72).

With respect to the other priorities which board members assigned to the various college programs, the academic area received by far the strongest support. At a time when the attention of provincial planners seems not to be focussed upon the academic function of the colleges, the views of board members should be carefully considered. Perhaps the enrichment of the quality of life which colleges offer through their academic programs has been underestimated! The role of the institutes in job-oriented education and training was strongly re-emphasized. Little support was expressed for inclusion of other program areas.

\section{(b) Role and Composition of Boards}

The results showed that board members support an important continuing role for the institutional boards. In particular, the strong support for policy development, approval of new college programs, planning and budgetary control suggests a determination to keep these institutional operations under board members' purview. Furthermore, while board members appear to recognize an important overall role for the Ministry of Education in matters such as program allocation, capital proposals, long range planning, and system rationalization, they hold the view that the boards should share these responsibilities. Evidently, whatever the future brings, the boards will not willingly surrender control of the system to a centralized authority. The idea of lay and community involvement through the board system, which has long been part of the British Columbia scene, is still very much embedded in the collective minds of college and institute board members. Planners, for example, need to take full account of this conclusion.

Another question arises as to the reason for such strong support of institutional boards. There are very few tangible rewards. which accrue from service on boards. The work is time consuming, usually involves long periods of travel, and certainly 
brings little financial gain. While there has been some suggestion that board membership engenders political advantage, such advantage is minimal, if indeed it exists at all. A possible conclusion is that board members see themselves as making an important contribution to the provision of a comprehensive, accessible, postsecondary educational system. In that context, they see advantages in continuing their role in the governance of a major social service as a factor in contributing to the quality of life in the province.

As publicly supported social institutions, the principle of direct election to the governing boards of colleges and institutes by the public at large has often been debated. There was minority support for this principle among the board members, particularly from school board appointees. There are, of course, a number of practical difficulties with the process but, quite apart from the expression of practical democracy, election of board members might raise colleges in the public consciousness and encourage debate as to their role and effectiveness. Certainly, the results of the study suggest further debate of the question.

The lack of support for wider representation on boards seems to be consistent with the inclination toward lay public control. There is a body of argument both for and against the inclusion of faculty, staff and student representation on boards, although, with the exception of those at B.C.I.T., current board members have no direct experience of wider representation. It is evident that for unspecified reasons, they are not in favor of wider representation.

The results showed a strong interest by all board members in the specific questions relating to collective bargaining, funding, and tuition fees. Despite the tendency in other Canadian provinces to introduce province-wide bargaining, board members in British Columbia seemed content to continue the current localized bargaining policy. This view may be interpreted as further evidence of the desire to retain a measure of local control within the system. Although collective bargaining can be a painful and time consuming process the majority of board members seemed to be willing to sustain this task rather than relinquish it to the provincial government level.

While the majority of respondents favored the policy of full provincial funding, a substantial minority were in favor of a return to some local funding. Of more significance was the fact that college board members and the more experienced board members were more supportive of a local contribution than institute and less experienced board members. It would be possible to compromise by introducing a form of "enabling" legislation which would "allow" colleges to seek local support. Given the trend to centralization, a policy such as the foregoing would do much to restore some measure of direct community control to local colleges.

Board members were not in favor of reducing or eliminating student fees. Clearly there is support for the idea that colleges should continue to provide greater access through reasonable fees. This view seems to be more prevalent with college board members than with institute board members. Despite the increasing institutional operating costs the majority of board members felt that fees were at 
an acceptable level. The provincial focus of the institutes was reflected in their board members' marginal support for increased tuition fees, and strong support for a non-uniform fee structure.

\section{(c) Extra-Institutional Governance}

The fact that only a small minority of respondents were in favor of the present organization at the provincial government level suggests that the structure may need revision. Evidently board members view education as an integrated entity, inclusive of the public schools, universities, colleges and institutes. This response, particularly applying to school board representatives on college boards, is characteristic of the early views of school district boards when colleges were initially being planned. While some support for a Ministry of Advanced Education at the provincial government level is apparent, there appears to be little sympathy with the current practice of isolating the universities from the rest of the educational structure.

The perspective on intermediary bodies is somewhat ambivalent. While the role seen for the council(s) is limited, there are certain activities in which council involvement is supported. On the other hand, the majority belief is that one council should be retained within the system. It seems that board members, while not entirely convinced of a council's specific responsibilities, are supportive of a body located between the Ministry of Education and the institutions. This suggests that further study of this phenomenon is indicated before definitive conclusions may be drawn.

\section{Einal Comment}

In a study such as this there is always a danger in drawing inferences from a set of data which is open to wide interpretation. However, there is a perceptible theme which underlies the response patterns to the many issues addressed in this study. The theme is the intention of college board members to preserve the values which have long characterized the colleges in British Columbia, as essentially comprehensive, community-based institutions, broadly accessible and lay governed. The boards are seen as determined to retain a high degree of involvement in framing the policies, provincial and regional, which affect the system. Clearly, there is a perceived role for a centralized authority, i.e., the Ministry of Education, but it is a role to be shared with institutional boards. The respondents seemed to be willing to continue a number of difficult tasks, such as collective bargaining, in the interests of preserving the current system.

It is instructive to gather the views of a group such as the members of institutional boards. In the main they appear to be committed and dedicated individuals with a strong sense of public responsibility. Their opinions, although rarely systematically assessed, deserve to be considered. Collectively and individually they bring a wealth of experience to the decision-making process. In planning for the future, the boards offer an important source of information. This study is one contribution to the process. 
31 Governing Boards in Postsecondary Education

\section{REFERENCES}

Gray, R.W. The Governance of Three Postsecondary, Two-Year Colleges in British Columbia, Canada. Unpublished doctoral dissertation, The University of British Columbia, 1975.

Kelly, G.O. A Study of Participation in College Governance. Unpublished doctoral dissertation, The University of Alberta, 1973.

Konrad, A.G. A Profile of Community College Trustees, Canadian Journal of Education. $2(2), 1977,65-77$.

Konrad, A.G. College Trustees View Their Selection, The Alberta Journal of Educational Research, XXII (3), 1977, 138-150.

Konrad, A.G. "Community College Boards: A Canadian Perspective". In New Directions for Community Colleges: Reforming College Governance, R.C. Richardson Jr. (ed.). San Francisco: Jossey Bass, 1975.

Konrad, A.G. Community College Boards, The Journal of the Association of Canadian Community Colleges IV (1) Winter/Spring, 1980, 95-107. 